CHAPTER TWELVE

\title{
TRADITION AND CREATIVE INSPIRATION: MUSICAL ENCOUNTERS OF THE MOLUCCAN COMMUNITIES IN THE NETHERLANDS
}

\author{
Rein Spoorman
}

\section{Musical Identities}

Ethnomusicological studies have been eager to stress music's importance in maintaining the identity of minority groups living in an urban setting. In describing Chicago's ethnic musical landscape, for example, Bohlman (2004: 437) argues how music is an indispensable part of the vocabulary of cultural difference:

In a community of new immigrants, for example, ethnic music that preserved culture, language, customs, folklore, and social and family interaction from the old country would have great importance because it embodied the memory of the past. [...] Ethnic music connects a community to a selected component of its past, but it does so to give meaning to the present. Thus, ethnic music should be understood as changing, not static.

Thus, music, besides being a carrier of memories and an important medium of identification with the past, is also instrumental in displaying identity in foreign surroundings (Research Group African Music 2006). Reyes-Schramm (1975: 103-104) shows the role of conga drumming in the Latin community of New York contributing to greater group solidarity, having people gravitate towards their own kind. Moreover, the success and recognition of Ray Barretto (as a Hispanic) serves 'as adaptive function toward upward social mobility' for drummers in East Harlem (ReyesSchramm 1975: 103-104). It is apparent that communities are internally often heterogeneous and subdivided by gender, age, or affiliation to subculture. But, there is also a sense of shared self-identification. Minority groups worldwide show an interest in the roots of their culture, either in the search for artistic inspiration or to show such reinvented cultural identity towards others.

This chapter discusses how, in the 1950s, people from Maluku came to the Netherlands and, ever since, have retained their cultural identity 
by musically expressing themselves through different genres and modes, ranging from the very traditional to today's World Music scene. In the Netherlands you can find just about every musical tradition that also exists in the Moluccas, such as choirs, tifa groups, Hawaiian ensembles and, above all, pop groups. In the late fifties, young Moluccans and Indo people played a prominent role in the emergent Dutch pop music scene, excelling in sweet songs of homesickness and longing. By the 1980s, many Moluccan artists had gained mainstream fame, not only in the Netherlands but also abroad, and in Indonesia. Using examples of popular bands such as Massada, Daniel Sahuleka or my own musical encounter with the Moluccan Moods Orchestra I will show, how Moluccan people are not only proud of their musicians doing well, but how - by gaining success among a wider audience - some bands and artists are accredited for being a role model to and a symbol of the social and cultural value of the minority group as a whole.

\section{Moluccan Music at Home}

Indonesia became a Dutch colony when the Dutch East India Company was formed in 1602. The administration was based in Java, but the Moluccas - scattered like a continent of islands across the sea between IndoChina and Australia inhabited by a mixture of peoples - were the central focus of the highly lucrative trade in spices.

Despite the Moluccan archipelago being renowned for its musical richness, to date little substantial research has been carried out on its music in context (Kartomi 1994, but see the early works by Van Hoëvell 1882; Joest 1892; Kunst 1945; and Heins and Van Wengen 1979). Today, old vocal traditions and ritual music exist side by side with external, more contemporary influences. Many musical forms can be linked to religious practice, i.e. music associated with animist beliefs, but also including that of the Christian missionary and Middle East-influenced musical expressions of the Muslim population. Many songs, orally transmitted from one generation to the next, are sung in local languages and are typical of a given area. Traditionally, however, much exchange between the islands and villages occurred, resulting in a wide repertory with variations on particular texts and melodies.

Next to a shared repertory there is a common musical idiom and context of performing. The one-headed drum tifa (also known as tiwa, 
tiwal, or tuba) is a common accompaniment for singing and dance. Non-melodic gongs are often played alongside such drum music. Gong ensembles with melodic gong-rows (totobuang) are mostly found in the central islands. Locally made flutes, multiple reed instruments, Jew's harp, and bowed and plucked string instruments such as bamboo zithers, are, generally, widely distributed, as are instruments of European and Middle Eastern origin. Alternate sung poetry, singing competitions and sung narrative, the latter often recounting historical events and claiming rights to land, forest or ocean are commonly found in the islands. Group dances in a circle, single-line, or multiple-line formations are widespread and, in some places, accompanied by singing, drums or non-melodic gongs. Such dances may be performed by men only, as in energetic war dances (sometimes referred to by the Central Moluccan cakalele), or they may consist of social and ritual dances performed by single or mixed sex groups. Whereas the latter dances have European roots, most Moluccan performing arts are primarily inspired by indigenous beliefs, which preceded the arrival of Islam in the $15^{\text {th }}$ century or Christianity in the 16th. Many of these 'early' dances are today still performed but cast into new folkloric choreographies.

It is obvious that as a result of the Dutch colonial impact European music, dances and instruments have been instrumental in shaping what is nowadays Moluccan musical culture at large. Thus, nineteenth-century European popular dance music formed the principal repertoire of the katreji ensemble of Ambon and environs; its music characterised by lead violin(s) or accordion and backed by guitar or similar plucked lutes, plus tifa.

In the course of the twentieth century, Moluccan music, especially on the central island of Ambon, would be significantly impacted by Western influences. Moluccan ensembles now trained themselves in playing new Western styles, such as foxtrot, cha-cha but also a repertory of local language songs (lagu-lagu Maluku), which were performed in new and exciting styles. Jaap Kunst - ignoring the fact that musical traditions necessarily are unstable and always subject to chance - wrote on the music of Maluku that "nowhere else in the archipelago - unless it would be on Sangir and Talaud and the Minahassa - does one find such a collapse of cultural identity. [...] Only sporadically can we find some of the unspoiled remains of the ancient cultural heritage' (Kunst 1945). Especially popular genres, often despised by Kunst and other early musicologists, play a role in the construction of national and regional identities. 
From 1925 onwards, and next to kroncong music, ${ }^{1}$ Hawaiian music would become immensely popular throughout the Dutch East Indies, although it particularly struck a chord in big cities, Batavia being the main centre of the new musical craze. Many of its most prominent musicians and especially (steel) guitarists came from Ambon though.

Hawaiian music would also be picked up in the Netherlands, where the music and especially the prominent steel guitar is appreciated for its 'exotic sound'. ${ }^{2}$ From the thirties onwards, new Hawaiian ensembles, both Dutch and Indonesian in origin, were established. The popularity of the genre, meanwhile, continued to grow. Because, at the start of the Second World War, the occupying forces forbade the listening to of jazz, Hawaiian music expanded tremendously.

\section{Hawaiian Comes to the Netherlands}

On 17 August 1945, and two days after the Japanese Emperor's surrender in the Pacific, Indonesian independence was proclaimed. By May 1950, and despite Dutch efforts to re-establish authority in the archipelago, through what were euphemistically called 'police actions', all federal states were absorbed into what was now the unitary state of the Republic of Indonesia, with Jakarta as its capital. However, the South Moluccas attempted to secede and on April 25 of that same year the Republik Maluku Sela$\tan$ (RMS) was proclaimed at Ambon. With its large Christian population and long history of collaboration with the Dutch, the region was among the few with a substantial pro-Dutch sentiment. A relatively large number of the professional soldiers serving in the Royal Dutch East Indies Army (KNIL) were recruited among the population of Ambon and the surrounding islands. The movement was suppressed by the end of the year and, after a special agreement with the Netherlands, some 12,500 former soldiers in the KNIL were transferred, together with their families, to

${ }^{1}$ Created prior to the Dutch arrival in the East, and influenced by Portuguese music would become one of the first popular genres to be spread through radio. Being a hybrid genre from the start, ever new instruments would be included such as saxophone, guitar, piano and trombone. There is also a strong influence of Hawaiian music (particularly steel guitar and ukulele) to be heard in some kroncong songs. For more kroncong, see Tangkau (1995 and 1996), Kloosterman (1996), and the contribution by Lutgard Mutsaers in this volume. Yampolsky (1991) contains some recordings.

2 The history of Hawaiian music in the Netherlands is described in detail by Lutgard Mutsaers (1992). The documentary Ga met me mee naar Hawaii (Come with me to Hawaii), directed by Hans Heynen (1994), tells the story of the Hawaiian cult in the Netherlands. 
the Netherlands. Here, they would establish a Republic of South Maluku government-in-exile (see www.republikmalukuselatan.nl). The Moluccan soldiers and their families were housed in camps, mostly in rural areas and near small towns, their stay supposedly being temporary. However, they would never return home. ${ }^{3}$

After the war, and during the Dutch struggle to keep their colony, there had been a boom in so-called Lowland Hawaiian (also Nederhawaiian) music, its most well-known exponent being the Kilima Hawaiians, which had already been founded back in 1934 by guitarist Bill Buysman. The group was at its most popular in the period $1945^{-1950}$, but in the fifties interest in Hawaiian music was generally on the wane. The arrival of the Moluccans in the Netherlands would change its fate, contributing to what was to be a genuine revival of the genre.

Due to the exceptional housing in camps, the relatively isolated living conditions in Dutch society, and the focus on their homeland, Moluccan communities in the Netherlands long nurtured an exclusive orientation towards their own culture. Numerous church choirs and flute orchestras were established in the camps, but secular music was also popular. Several camps organized so-called 'Ambon evenings', probably styled after the 'Indonesian nights' found elsewhere in the country, and which were also attended by Moluccans. Hawaiian music was popular at such events until it was finally supplanted by Indo rock's fame of the late fifties. Even before the arrival of the Moluccan soldiers to the Netherlands, navy man Mingus (Johnny) Pelasula and his band Suara Timur (Voice of the East) brought Hawaiian music. The Honimoa Singers from Camp Lunetten performed throughout the country in $195^{2}$.

George de Fretes, inspired by famous Hawaiian guitarist Sol Hoopi, was without a doubt the best known of the Moluccan Hawaiian musicians in the Netherlands. In the spring of 1938 , at a competition in Surabaya, De Fretes and his band were voted 'Champion of the Archipelago', and now they had been renamed the Royal Hawaiian Minstrels. The Minstrels were the most popular and best paid band in the whole of the Dutch East Indies until the outbreak of World War Two. In 1958, De Fretes came to the Netherlands as a stowaway on the ship Johan van Oldebarneveldt. However, his fame preceded him and Phonogram producer Jan de Winter

${ }^{3}$ For a more extended analysis of the complicated story of the disbanding of the KNIL see Manuhutu and Smeets (1991); Smeets, and Steijlen (2006); Steijlen (1996); Van Amersfoort (2004). 
sent a message by telegraph to the ship hoping to contract him. On the 1st September 1958, De Fretes performed for the first time in the Netherlands, at a day for record traders in Utrecht, together with the re-formed Royal Hawaiian Minstrels. Such was their success, that a few weeks later, De Fretes had his own radio show (with the AVRO) and a special $195^{8}$ Christmas special on national Dutch television. Here, he played Tickling the strings, a difficult song, which he played blindfolded, especially for the occasion.

De Fretes was not the only Moluccan to gain Hawaiian fame. His former pupil Rudi Wairata - who had already arrived in the Netherlands - had successes with his band the Mena Moeria Minstrels, in which De Fretes ex-wife Joyce Aubrey featured as a singer and Lou Lima (Ming Luhulima), another well-known Moluccan artist, was head of the orchestra. When doing kroncong repertoire or performing Moluccan and Indonesian songs, the group played under the name the Amboina Serenaders. ${ }^{4}$ The Amboina Serenaders had a bestselling song with Ik wil klappermelk met suiker (I want coconut milk with sugar).

Nevertheless, it was the Royal Hawaiian Minstrels (with Aubrey rejoining the group in 1958) that continued to be successful both in the Netherlands and abroad. In 1963 they and other artists grouped together and toured American military clubs in Germany under the name of the Honolulu Holiday Show. In 1966, De Fretes went on another tour of Germany, and this time also Switzerland and Scandinavia, together with Indo-rock legend the Tielman Brothers, whom he knew from Indonesia. The same year, he recorded an album with the German orchestra of Frank Valdor before leaving the Netherlands to settle permanently in America. ${ }^{5}$

4 In the 6os, Hawaiian bands continued to operate in the Netherlands using different names when doing kroncong, Moluccan or Indonesian songs. Today it is still hard to find bands that specialize in kroncong, and domiciled Indonesians are the biggest names in the genre. The Moluccan family group Rayuan Samud'ra are still requested all over the country and regularly perform at major Indonesian events, such as the Pasar Malam in The Hague; see, among others, Bennekom (1987); Boekholt (1980); and Buysman (1965).

5 From 1969 to 1981 De Fretes lived in Los Angeles where, on 19 November of that year he died of a heart attack. He was buried next to his idol Sol Hoopi, their graves being decorated with a similar bronze plaque. George had long ago surpassed the fame of his idol (Boekholt 1981, 1982). 


\section{Intermezzo: Rock and Roll in the Low Lands}

The Timor-born Tielman Brothers were the first and most famous exponents of a genre that rocked the Netherlands in the late 1950s. The music, performed by musicians from the former Dutch East Indies, was inspired by rock ' $n$ roll music from the States and the instrumental music of the Shadows, the Ventures and the String-A-Longs. While, much later, the music earned the (somewhat derogatory) nickname 'Indo' rock, there has been little attention for the Moluccan input into this vibrant scene. In the Moluccan camps, countless bands were formed and although initially performing mainly in their own circles, some Moluccan groups soon made it outside the camps. Groups such as Black Magic (with Boy Tahalele, Paul Tureay, Mook and Michel and Dolf Riupassa), White Waves (the brothers Andy, Eddie and Sammy Noya), or the Black Diamonds consisted, as a rule, of boys, but were occasionally supplemented by a female lead singer, such as Lisa Sapury's role for the band The Ruby's. An exception was Martha 'Poppy' Matulessy, who was the central member of the band Poppy \& her Popcats. Like the Tielman Brothers, many of these bands would perform abroad, especially in Germany (see Mutsaers 1989). With the emergence of the beat music of the Beatles, and in their wake the Stones, the Kinks and the Who, Indo-rock lost popularity and only experienced a revival in the 1980 s.

In the late '6os, the psychedelic group 'Dragonfly' from the province of Zeeland won the hearts of Dutch audiences. The band usually performed with painted faces and, thus, very much suited the zeitgeist of flower power. During concerts, Dragonfly's songs are announced by Dutch writer Hans Verhagen, who adds to the band's prestige. Their guitarist Rudy de Queljoe was, in those days, referred to as the 'Dutch Jimi Hendrix'. After an extensive tour of the Low Lands, featuring as a support act for Pink Floyd, they recorded a first song for Philips. Due to extensive coverage by the Dutch youth magazine Hitweek, Celestial Dreams reached 33 in the charts. Its successor, Prince of Amboyna, was less popular and, in 1969, de Queljoe parted company with the group to join Brainbox and later the famous Dutch bands Cuby and the Blizzards and Vitesse. De Queljoe's success and recognition is of great importance, not only in terms of him being a good guitarist, but also as a role model for the Moluccan community. 


\section{Mainstream Sounds}

Meanwhile, music back at home had evolved. The European harmonic and melodic idiom is still to be heard in the Christian hymns sung by choirs and congregations, or performed by flute or wind bands. The Christian faith also forms the basis of newly composed religious songs. In the 1960 s and 70 s more Western music would reach the Moluccas, particularly electric amplified pop music, but also (although to a lesser extent) new musical trends were styled after Middle Eastern and Indian popular music. Today's Moluccan pop and folk music is quite diverse, embracing abovementioned influences, but also being shaped by what in Indonesia is commonly referred to as pop daerah (regional pop), in this case popAmbon, pop Ternate, etc. Several of these songs have become part of the national heritage of Indonesia, and can be found in written song collections and are taught in schools. ${ }^{6}$ Nowadays, local popular music uses local language and is a mix of hybrid urban popular music styles, commonly found throughout Indonesia. Similar encounters with other musical styles, genres and scenes happened among those Moluccans living in the Netherlands, a country that, by the 1970s, for better or worse, had increasingly become a home away from home.

The popularity of Indo-rock had taken Moluccans out of the camps and into contact with Dutch society. Not only the musicians themselves, but also their Moluccan fan base suddenly appeared in Dutch venues. Encounters in nightlife between Moluccan and Dutch youngsters - especially Moluccan boys and Dutch girls - would become a major source of mixed marriages. However, on other terrains participation of Moluccans in Dutch social life would remain fairly low for the time to come (Smeets and Steijlen 2006). It took until the late 1970s for Moluccans to increasingly focus on their position within Dutch society.

One of the foremost Moluccan bands of the mid-seventies was Massada, with the brothers Johnny and Eppy Manuhutu, Chris Latul, Saba Usje Sabander and Zeth Mustamu. Massada was founded in 1973 and soon had a reputation for being an excellent live act and, consequently, the

6 The total number of folk songs known as Moluccan songs is estimated at over 200. The 'official' school song collection Muchlis and Azmy (1978) contains a 164 and Simanjuntak (1984) another 17, all represented with number notation. The folk songs can be heard on audiocassettes from the 1970s-1980s, performed by groups such as Beilohy Group, orkes Rame Dendang and Masnait Group. Furthermore, there are a large number of websites complete with lyrics of what is known nowadays as Moluccan 'standard repertoire'. 
band had a loyal fan base. Their Moluccan identity is especially stressed on their second album, Pukul Tifa (Playing the Tifa Drum, 1979). The album contains a number of long, instrumental pieces and popular songs such as Latin Dance, Dansa, Arumbai, clearly signaling the then popular Latin sound, as played by Carlos Santana and the likes, but theirs is a music with an 'oriental' touch.

From the Malay lyrics it can be judged that the band members sympathize with the ideal of independence for the South Moluccas, but there is also plenty of space for reference to shared traditions. On the album Pusaka (Heirloom), the traditional sound of the totobuang can be heard in the song Toto Buang Tomah. The totobuang is one of the characteristic Moluccan instruments, consisting of a row of small, horizontally-laid melodic knobbed kettle gongs. ${ }^{7}$ It is considered an ancient instrumental form of music, which predates the influences of Islam, Christianity, and the West. In 1980, the band would release Sajang é, an old Indonesian folk song, here performed complete with a women and children's choir. The song is hardly representative of Massada's repertory, but it became an instant number one hit. A success with consequences as the band was soon to find out. During live shows, people now want to hear more songs à la Sajang é, while fans of the first hour quit. After this erstwhile mainstream success the group continued to tour and they made a number of studio albums, but in 1986 Massada stopped due to the lack of success.

In addition, Cheyenne, a funk group, experienced its greatest successes at the end of the seventies. In 1978, their first single, Separated Love, made it into the charts. When Cheyenne dissolved in 1982, front woman Julya continued as Julya Lo'ko and developed into a sought after background singer. She joined the 'super group' Suara Maluka Band, in which Ais Lawalata, Neppy Noya, Daniel Sahuleka and Chris Latul all perform. ${ }^{8}$

7 The instrument is part of the larger gong-chime culture of Southeast Asia, such as the kulintang of the Southern Philippines. Totobuang is also used in the break-theme Perasaan Maluku (Moluccan Feelings) on the Moluccan Moods LP (SPN 002), composed by Zeth Mustamu and played by Rudy Tuhusula. Rudy Tuhusula is also known for his modern compositions for totobuang.

8 From the mid-nineties she is also successful as a solo artist and widely admired in Dutch theaters. With Mathilde Santing and Astrid Seriese, Julya wins the Knokke Festival. Her career gets an additional boost after she is awarded the Silver Harp of Conamus (an institute offering support to Dutch easy-listening) and she plays an impressive role as 'leading lady' in the 'Labyrinth Project' of Jazz musician Jasper van 't Hof and Cesar Zuiderwijk, drummer of rock band Golden Earring. Today, she performs in Dutch theatres with more new programmes, along with guitarist Erwin van Ligten, percussionist Sandra Sahupala and guitarist Arnold van Dongen. Other members of Cheyenne also enjoy 
Perhaps the most successful of all is Daniel Sahuleka. Sahuleka, born in $195^{\circ}$ in Java, was raised in the Netherlands, and initially lived in a Moluccan camp. In 1976 he was discovered as a singer/guitarist. His debut album Sahuleka (1977) contains funky up-tempo songs and atmospheric ballads. Sahuleka 2 was released in 1978 and the single taken from this album, Do not Sleep Away the Night topped the charts in Indonesia for seven weeks. However, his third Sunbeam (1981) is his bestselling album and the singles taken from this recording finally managed to find their way into the Dutch charts. By that time, Sahuleka was enjoying an unprecedented popularity in Indonesia. On the album RahASIA (1995), Sahuleka not surprisingly goes back to his Indonesian roots. The album contains performances of well-known traditional songs, such as Mande Mande, Bulan Pakai Pajung, Lah Ikan Gabus and Dibawah Bulan Purnama.

\section{Moluccan Moods in Amsterdam}

The late 1970s quest for a new Moluccan identity surfaced most clearly in Amsterdam. Initiatives for novel cultural expressions were largely triggered by a small group of innovators, consisting mainly of intellectuals and artists or groups that lived outside the Moluccan quarters in major Dutch cities. In the late seventies, Amsterdam in particular grew into a kind of laboratory for Moluccan culture and events, where youngsters took on all sorts of art forms. The intent to reproduce 'authentic' cultural expressions from the Moluccas faded into the background and new syncretism forms were the fashion, providing traditions with new meanings and showing how Moluccan youth were willing to announce their presence in Dutch multicultural society.

From 1982 onwards, the popular music venue Paradiso in Amsterdam regularly staged concerts under the title of 'Moluccan Moods'. Each month, one or more Moluccan bands, recruited from all over the Netherlands, were presented. These series were attended by young Moluccans from all over the country and Paradiso was regarded as the main stage of the Moluccan circuit. The evenings, organized by Eddy Tutuarima, along with Zeth Mustamu of Massada and Eddy Lekranty, the guitarist of Cheyenne, were not only meant to raise awareness of Moluccan music among a wider audience, but also to encourage those same Moluccan musicians.

individual success, such as Julya's brother Eddy Lekranty (Moluccan Moods Orchestra) and bass player Michael Peet (Jan Akkerman, TC Matic). 


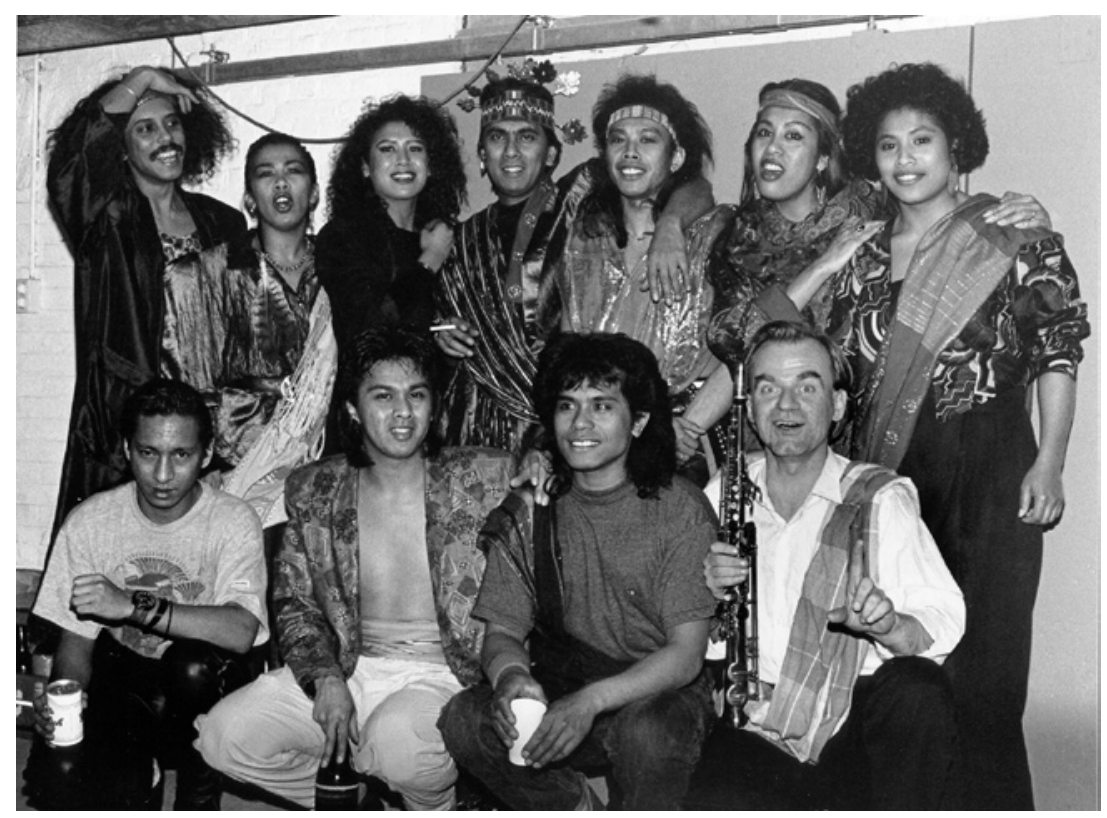

Image 12.1 Moluccan Moods Orchestra, with author sitting at the bottom right (photo courtesy of the author).

Within this framework, and supported by the Netherlands Foundation for Pop Music, an album was released in 1982 covering ten of the best bands that had performed at the Moluccan Moods programme so far. A year later, a second album, Moluccan Moods Live, followed. Both albums contain different styles, such as the experimental music of Perlawan, the new wave group Nuscera or the socially critical ska-inspired rock of H-Gang (see the contribution by Steijlen to this volume), some of which are not inherently associated with Moluccan cultural life. In later years, Paradiso continued to act as a major centre where Moluccan events were organized. ${ }^{9}$

It was the late Eddy Lekranty of Cheyenne fame who, in 1984, also started the Moluccan Moods Orchestra (MMO), a band I would join in

9 In the fall of 1983, a festival under the name of Manggurebe (Compromising the finish) was simultaneously organized by the Panggayo project in two Amsterdam clubs, Paradiso and the Melkweg. The shows offered a range of Moluccan arts and culture and were partly intended to encourage interaction between Amsterdam Moluccan youth and other ethnic minority groups. 
1987 as a saxophonist and flute player. MMO is a music group that consists of second and third generation immigrants, whose parents came from the Central and Southeast regions of Maluku Province. They first started as a group accompanying Moluccan artists in the above described Paradiso concert series. However, in the long run, the band would develop its own new 'melting pot' style, blending musical styles from West and East, with the latter mostly referring to the Moluccas and Indonesia, but the music of Japanese composer Ryuichi Sakamoto was also influential. There proved to be a market for the band, especially in the upcoming world music circuit and their music was very well received by the music press. Festival concerts and radio and television performances soon followed and studio sessions for SFB-Radio Berlin resulted in a first album, Wakoi (Child). The second album Sedjarah (History), released on the Dutch PAN Records label provides an overview of their musical in the period 1988-1999. The group continues to develop new repertoire on the basis of traditional folk songs, but also new compositions are made mixing traditional Moluccan elements with international pop music.

From the musical practice of the Moluccan Moods Orchestra, I learned how musical traditions were taken as a source of inspiration and a starting point for new forms of music. For instance, the song Batu badaun (Leafy rock), tells the legend of a widow. Disappointed with her disobedient children she disappears into the leafy rock. Or the song Lembe-Lembe, a song that describes what happens at the beach when fishermen return home. It was during rehearsals, especially when jamming freely with fellow musicians, that I first encountered a body of folk songs that everybody seemed to know by heart. A popular music repertory that featured popular songs from the 1950s and earlier, but also harmonized folk songs (lagu rakyat) or so-called 'regional songs' (lagu daerah) from - or at least associated with - Maluku. They are still performed at 'arts nights' and cultural shows (live and televised) as tokens of the identity of Maluku.

\section{A Melting Pot of Cultures}

Twentieth-century mass media facilitate the mixing of popular, folk, and classical musical elements and styles. Music now seems to travel freely from one part of the world to another. In pop music, internationally oriented by nature, this integration of musical styles - many originating outside the Northern hemisphere - has penetrated the deepest. Thus raï music, reggae, hip-hop, the many Afro-Caribbean and South American 
types of music and all kinds of crossovers have become an accepted phenomenon among a broad audience. Recently, the diasporic world music of Moluccan artists such as Monica Akihary and Maurice Rugebregt has also found its way not only to a broad audience but also to its home country, with Moluccan artists now performing in Indonesian jazz clubs, at the Jakarta International Java Jazz Festival and Ambon Jazz Plus. ${ }^{10}$

After graduating from the Rotterdam Conservatory in 1996, Maurice Rugebregt travelled to the Moluccan capital Ambon in search of his roots. He bought tapes of local folk music and taped himself and other people singing traditional songs. Maurice selected several Moluccan traditionals and arranged and recorded them accompanied by some of the best Dutch jazz, Latin and Moluccan musicians. The result is Sioh Maluku (Nostalgia for the Moluccas), a true world music CD containing vibrant Brazilian, jazz and pop arrangements of traditional Moluccan songs.

The roots of Monica Akihary and her band Boi Akih lie in traditional Moluccan music (lagu lagu), which is known for its refined melodic twists and impressive polyphonic singing. Pop, jazz and world music elements are then added. After her 2004 album Uwa I, she released the CD Princess Akih, a duet with Dutch guitar virtuoso Niels Brouwer. On these albums, Monica develops an improvisational approach and her very own singing style. Monica sings in her father's mother tongue, the language of Haruku Island. Brouwer and Monica have integrated this language into their very own musical style, rooted in Indonesian, South Indian and European classical music along with jazz. Yalelol (the non-physical being), her band Boi Akih's fifth album, makes good use of many influences ranging from Indonesian traditional music to blues, Arabic rhythms, West African songs and more. In recent years, Monica frequently performs in other countries, including Indonesia. In 2009, she and Boi Akih played for the first time in Norway, Bulgaria and Tunisia, and later that year the band toured in Mexico and Indonesia. The latter was a special tour, because for the first time they performed in Ambon before a delirious audience on the

10 Recent years also saw cooperation between artists from the Moluccas and Netherlands. Moluccan Music Theatre Ensemble is a project of Anis de Jong, Nel Lekatompessy and Rence Alfons. In August 2009 the performance Paku Coklat (Cloves) was staged at Taman Budaya di Karang Panjang in Ambon. It formed a prelude to bigger scenarios in the form of an 2011 opera on Saparua (Fort Duurstede - outdoor show). The project was supported by Museum Maluku di Belanda, Culture and Tourism Office Province of Maluku, Pemerintah Daerah and the Dutch Embassy in Jakarta (Erasmus House). 
Lapangan Merdeka (Freedom Square). Boi Akih received wonderful reviews in the Indonesian press.

\section{Conclusion}

If one thing can be learned from the development of Moluccan music then it is that cultural identity, understood as a collective, shared history of individuals affiliated by race or ethnicity has many faces and continues to experience transformations. The musical developments, including those on the Moluccas, have not stood still and over the years the Moluccan repertoire has been adapted, modernized, westernized and again blended with other 'Eastern' traditions. Traditional music and folklore are a living tradition and the same old songs, orally transmitted from one generation to the next, are still relevant. Songs that were popular when a first generation of Moluccans came to the Netherlands in 1951 are still passed on to subsequent generations and still form the musical basis for many Moluccan music groups. This traditional music is still played - often modernized - at Moluccan weddings, parties and kumpulans-(village) meetings and events, but it is also performed by well-known bands and artists that play the current Dutch stage circuit, such as Ais Lawalata, Daniel Sahuleka, Moluccan Moods Orchestra (MMO), Julya Loko, Monica Akihary and many others. Most of their music is very rhythmic and many of these bands write lyrics in Ambon Malay and arrange existing new or traditional Moluccan songs. In addition, there are groups that incorporate elements of traditional music into modern pop and jazz, as Massada did back in the late 1970s. Moluccan Moods Orchestra (MMO) made the modernization of traditional music its trademark, performing well-known Moluccan evergreens from the ' 50 s with a pop instrumentation and contemporary manner.

Listening to Moluccan music in the Netherlands, we hear various (oftentimes mutual) strategies to deal with musical traditions. One of them is the 'purist' approach, common for revival groups that perform what they believe are the unspoiled remains of an ancient cultural heritage. Another approach can be seen in the popular forms of folk music, which nowadays are played on modern instruments, such as synthesizers, and are still very popular at Moluccan weddings and parties. Thirdly, there is tradition as a source, inspiring the creation of contemporary music, a practice especially popular among Moluccan pop artists. And lastly, there is mainstream popular music, such as rock, funk, Latin, or hip hop to which characteristic 
elements of Moluccan culture are added as if they were identity markers. ${ }^{11}$ Of course, the music of Moluccan artists today is not limited to what one could typically call 'Moluccan'. But, for the good listener, there is always something Moluccan to be heard; by using tools or typical characteristics, or taking the language or traditional singing style or rhythms as a starting point for new Moluccan sounds.

\section{References}

Amersfoort, H. van. 'The waxing and waning of a diaspora: Moluccans in the Netherlands, 1950-2002', Journal of Ethnic and Migration Studies 30-1: 151-174, 2004.

Bennekom, Nel van. 'Hawaii, de droom van mister Aloha', Gooi- en Eemlander, 23 May 1987 .

Boekholt, Ralph. 'Rudy Wairata is still tickling the strings', Moesson, 15 October 1980.

—. 'George de Fretes, overleden', Moesson, 1 December 1981.

_ . 'George de Fretes bleef altijd zichzelf', Moesson, 15 January 1982.

Bohlman, Philip V. 'Ethnic music', in: J.R. Grossman, A.D. Keating and J.L. Reiff (eds.), The encyclopedia of Chicago. Chicago, IL: University of Chicago Press, 2004.

Heins, E. and G. van Wengen. 'Maluku (Molukken)', in: P. Collaer (ed.), Musikgeschichte in Bildern: Südostasien. Leipzig: VEB Deutscher Verlag für Musik, 1979.

Hoëvell, G.W.W.C. Baron van. 'Twee zangen in de Ambonsche landtaal (Bahasa Tanah)', Tijdschrift voor Indische taal-, land- en volkenkunde 27: 69-89, 1882.

Joest, W. 'Malayische Lieder und Tänze aus Ambon und den Uliase (Molukken)', International archives for ethnography 5: 1-34, 1892.

Kartomi, Margaret J. 'Is Maluku still musicological "terra incognita"? An overview of the music-cultures of the province of Maluku', Journal of Southeast Asian Studies 25-1: 141-171, 1994.

Kloosterman, R. (ed.). 'Kunst en populaire cultuur'. Theme issue, Migrantenstudies 12-4: $175^{-258,} 1996$.

Kunst, Jaap. Een en ander over de muziek en den dans op de Kei-eilanden. Amsterdam: Koninklijke Vereeniging 'Indisch instituut', 1945.

Manuhutu, W. and H. Smeets (eds.). Tijdelijk verblijf: De opvang van Molukkers in Nederland, 1951. Amsterdam: De Bataafsche Leeuw, 1991.

Muchlis and Azmy. Lagu-lagu untuk sekolah dasar dan lanjutan: Jil. 2: Lagu rakyat. Jakarta: Musika, 1978.

Mutsaers, Lutgard. Rockin' Ramona. 's-Gravenhage: SDU, 1989.

—. Haring \& Hawaii. Hawaiianmuziek in Nederland 1925-1991. Amsterdam: Mets, 1992.

Research Group African Music. 'African Music in Vienna - Seen through the eyes of various African artists'. Paper, Symposium 'Urban Ethnomusicology', Universität für Musik und darstellende Kunst Wien, March, 2006.

Reyes-Schramm, Adelaida. 'The role of music in the interaction of Black Americans and hispanics in New York city's East Harlem'. PhD, Columbia University, Ann Arbor, Michigan, 1975 .

Simanjuntak, W.S. Indonesiaku, persadaku. Jakarta: Titik Terang, 1984.

11 An example is the YouTube clip of the band Ambonwhena Aaratuaman playing mainstream hip hop but performing in the Moluccan language, and playing together with local Maluku youth, which is intermixed with images from the islands and people of Maluku. 
Smeets, H. and F. Steijlen. In Nederland gebleven: De geschiedenis van Molukkers 1951-20o6. Amsterdam: Bakker, 2006.

Steijlen, F. RMS: Van ideaal tot symbool. Moluks nationalisme in Nederland 1951-1994. Amsterdam: Het Spinhuis, 1996.

Tangkau Melanie. 'Een korte geschiedenis van de Krontjong (deel 1)', Pasarkrant (Winter 1995). Den Haag: Tong Tong, 1995 .

. 'Een korte geschiedenis van de Krontjong (deel 2)', Pasarkrant (Spring 1996). Den Haag: Tong Tong, 1996.

\section{Discography}

Akih, Boi. Boi Akih. Invitation Records/ EMI, 1997.

Lawalata, Ais. My Maluku. Weert: Telstar TCD 10157-2, 1993.

Massada. Pukul tifa. Weert: Telstar TCD 101082/1990, 1979.

Moluccan Moods. Moluccan Moods. Amsterdam: SPN / 002 LP, 1982.

Moluccan Moods Orchestra. Sedjarah. Leiden: PAN/RMP 168 CD, 1999.

Sahuleka, Daniël. RahAsia. Hilversum: Sunflight 0010412 55, 1995.

Yampolsky, P. (ed.) Music of Indonesia vol. 2: Indonesian popular music: Kroncong, dangdut, and langgam jawa. Washington: Smithsonian/Folkways Records, 1991.

\section{Videography}

Hans Heijnen. Ga met me mee naar Hawaii, documentary directed by Hans Heynen for VPRO-TV. Hans Heijnen Films: Nijmegen, 1994.

\section{Websites Consulted}

www.popinstituut.nl/

www.indorock.pmouse.nl/

www.andytielmanproductions.com/

www.storyofindorock.nl 